\title{
KONFLIK HUKUM ISLAM DAN SOLUSINYA
}

\author{
Usman
}

Fakultas Syariah dan Hukum Universitas Islam Negeri Alauddin Makassar

\begin{abstract}
This paper tries to analyze the problem of conflict of Islamic law and its solution. This analysis will be preceded by the introduction of conflict terminology and its implementation, then analyzed theoretically the problems that occur as part of the effort to resolve the conflict of Islamic law. Conflict as a result of ijtihad is an unavoidable necessity. Therefore the attitude to be taken is to be open (inclusive) in addressing every issue and dissent among Muslims and not vice versa, that is being fanatical. Conflicts arising from differences of opinion among Islamic jurists are furu'iyah (branch), not on Islamic law which is ushuliyah (principal). Therefore, the approach used in resolving every Islamic legal conflict resulting from ijtihad is a reformative and tolerant approach to any difference.
\end{abstract}

\section{Keywords:}

Islamic Law, Conflict, ljtihad

\begin{abstract}
Abstrak
Tulisan ini mencoba menganalisa persoalan konflik hukum Islam dan solusinya. Analisa ini akan didahului dengan mengemukakan terlebih dahulu terminologi konflik dan implementasinya, kemudian dianalisis secara teoritis persoalan-persoalan yang terjadi sebagai bagian dari upaya menyelesaikan konflik hukum Islam. Konflik sebagai hasil ijtihad merupakan sebuah keharusan yang tidak bisa dihindari. Oleh karena itu sikap yang harus diambil adalah bersikap terbuka (inklusif) dalam menyikapi setiap persoalan dan perbedaan pendapat di kalangan umat Islam dan bukan sebaliknya, yaitu bersikap fanatik. Konflik yang lahir dari perbedaan pendapat di antara para ahli hukum Islam bersifat furu'iyah (cabang), bukan pada hukum Islam yang bersifat ushuliyah (pokok). Oleh karena itu, pendekatan yang digunakan dalam menyelsaikan setiap konflik hukum Islam hasil ijtihad adalah pendekatan reformatif dan toleran terhadap setiap perbedaan.
\end{abstract}

Kata Kunci:

Hukum Islam, Konflik, ljtihad 


\section{A. PENDAHULUAN}

K

onflik merupakan persoalan aktual yang sering terjadi dalam realitas kehidupan sosial, politik, dan ekonomi. Namun konflik dalam diskursus ini bukanlah dimaksudkan sebagai yang dipahami dalam terminologi ilmuilmu sosial, tetapi dimaksudkan sebagai suatu perbedaan pendapat dan pemahaman terhadap hukum-hukum Islam hasil ijtihad para ulama.

Konflik hukum Islam hasil ijtihad, tidak perlu disikapi secara berlebihan apalagi dipandang sebagai sesuatu yang dapat melemahkan posisi hukum Islam, akan tetapi justru sebaliknya dapat memberi ruang gerak yang lebih dinamis dan fleksibel bagi umat Islam untuk mendinamisasikan hukum Islam. Dengan keluwesan dan fleksibilitas hukum Islam seperti itu, umat dapat memilih pendapat mana yang lebih sesuai dengan kondisi, waktu, ruang, dan tempat dimana hukum itu akan diberlakukan. Sehingga dari sini bukan tidak mungkin harapan Nabi mengenai perbedaan pendapat itu adalah "rahmah" akan terealisir.

Persoalannya kenapa konflik hukum Islam itu terjadi ? Jawabannya terkait erat dengan proses pemahaman atau penafsiran terhadap dalil-dalil nash Al-Qur'an dan Hadis Nabi saw. Kedua sumber hukum Islam ini memuat ketentuan-ketentuan hukum Islam yang berbeda-beda, disamping memuat ketentuan-ketentuan yang bersifat definitif (qaht'i) juga memuat ketentuan-ketentuan yang bersifat spekulatif (dhanni), begitu pula dengan ijma dan qias. Meskipun daya spekulatif untuk kedua dalil yang disebut terakhir lebih banyak merujuk pada faktor-faktor external.

Berpijak pada realitas konflik atas pemahaman terhadap dalil-dalil nash di atas, tampaknya tidak terlalu disangsikan manakala Yusuf Al-Qardhawi sebagaimana juga dikutip Huzaimah, menjastifikasi adanya "kemestian" konflik dalam lapangan hukum Islam, dan tidak mungkin dapat menghidarinya, karena pengungkapkan hukum-hukum di dalam nash-nash Al-Qur'an sebagian menggunakan pola-pola spekulatif. ${ }^{1}$ Lebih dari itu didukung pula dengan tabiat manusia yang mempunyai kecenderungan dan karakteristik yang berbeda-beda. Ini berarti bahwa konflik terjadi bukan sebatas gagasan tanpa dasar dan asal, bahkan keberadaannya dilegitimasi oleh Agama.

Berbeda dengan itu, di masyarakat pemahaman tentang konflik hukum Islam dikesankan bahwa kitab-kitab fiqhi berisi persoalan-persoalan hukum yang kontroversial sebagai akibat dari pendapat peribadi yang sabyektif kemudian ditransfer secara praktis kedalam agama sehingga menjadi bagian yang harus diamalkan. Jika anggapan demikian diamati secara lebih serius dan mendalam serta didasarkan pada akal sehat, maka akan ditemukan bahwa ketentuan hukum Islam tersebut berasal dari Kitab Allah, yakni Al-Qur'an dan Hadis Nabi saw., ${ }^{2}$

Kedua kitab yang disebutkan terakhir, mesti menuntut "metodologi" sebagai upaya untuk memahami dan mendeduksi hukum-hukum fiqhi dari sumber aslinya

\footnotetext{
${ }^{1}$ Huzaemah Tahido Yanggo, Pengantar Perbandingan Mazhab, (Jakarta: Logos, 1997), h. 64

${ }^{2}$ Ibid., h. 63
} 
yang tentu formulasinya tidak selamanya sama, pada akhirnya bisa dipastikan akan melahirkan aturan-aturan hukum yang berbeda-beda pula, terutama di seputar persoalan yang bukan bersifat prinsip atau substansi ajaran. Ruang perbedaan tersebut akan semakin berpeluang ketika masing-masing kelompok memberikan penekanan yang berbeda-beda pada dalil-dalil di luar dalil-dalil yang disepakati.

Berlatar dari perspektif di atas, tulisan ini mencoba menganalisa persoalan konflik hukum Islam dan solusinya. Analisa ini akan didahului dengan mengemukakan lebih dahulu terminologi konflik dan implementasinya, kemudian selanjutnya dianalisis secara teoritis persoalan-persoalan yang terjadi sebagai bagian dari upaya menyelesaikan konflik hukum Islam itu sendiri.

\section{B. PENGERTIAN KONFLIK DAN IMPLEMENTASINYA}

Secara umum konflik dipahami sebagai suatu bentuk ketegangan atau sebagai akibat ketidak sepahaman terhadap suatu masalah atau peristiwa hukum dalam nash. Dalam bahasa agama konflik hukum Islam disebut ikhtilaf atau perbedaan pendapat atau saling berlawanan dan saling bertentangan. ${ }^{3}$

Sedangkan menurut istilah, konflik hukum Islam bermakna berlainan pendapat antara dua atau beberapa orang terhadap suatu masalah atau peristiwa tertentu, baik berlainan itu dalam arti "tidak sama" atau dalam arti "bertentangan". ${ }^{4}$ Istilah konflik dalam studi ini digunakan dalam pengertian "perbedaan pandangan dan pemahaman terhadap hukum Islam hasil ijtihad para fuqaha. Perbedaan pandangan dan pemahaman tersebut disebabkan karena perbedaan metodologi yang digunakan mereka dalam memahami dan menetapkan hukum terhadap satu masalah atau kejadian. Perbedaan tentang hukum wudhu seorang laki-laki yang menyentuh perempuan dan hukum membaca surat al-Fatihah bagi ma'mun dalam sholat misalnya merupakan salah satu contoh yang dapat melahirkan konflik pemahaman dan penafsiran. ${ }^{5}$

Berkaitan dengan konflik yang disebutkan terakhir, secara akumulatif ditemukan di dalam Al-Qur'an sebanyak tujuh dalil-dalil nash yang berimflikasi konflik pemahaman dan penafsiran dengan berbagai bentuk derivatifnya, yaitu pada surat 23: 81, 30: 22, 2: 164, 45: 4, 3: 190, 10: 6 dan surat 4: 81. Sedangkan akar katanya, baik menggunakan fiil Madli, maupun fiil Mudhari, juga menggunakan isim fail dan maf'ul, serta menggunakan bentuk singular atau plural ditemukan pula sebanyak lebih dari 20 kali. $^{6}$ Ini berarti bahwa Al-Qur'an sebagai sumber hukum Islam mengklaim adanya konflik terhadap nash-nash hukum terutama nash hukum yang bersifat furu'iyyah.

\footnotetext{
${ }^{3}$ Ibid., h. 48

${ }^{4}$ Ibid.,

5 Ibid., h. 49

${ }^{6}$ Dewan Redaksi, Ensiklopedi Islam, (Jakarta: PT. Ichtiar Baru Van Hoeve, 1993), 134-135
} 
Dalil-dalil nash yang berimflikasi konflik sebagaimana dikemukakan itu, menunjukkan bahwa fluralitas hukum hasil ijtihad ulama demikian masif terjadi sejak masa shahabat sampai masa sesudahnya. Dalam hubungan ini, Ali Hasan, seorang ahli hukum Islam, mengakui kenyataan ini dan masih akan terus berlangsung. Mereka beselisih faham terutama dalam masalah furu'iyyah sebagai akibat dari keanekaragaman sumber dan aliran dalam memahami nash dan mengistimbathkan hukum terutama yang tidak ada nashnya. ${ }^{7}$ Perselisihan terjadi antara pihak yang mengusung pemikiran rasional-modernis dengan pemikiran tradisional. Pemikiran rasional-modernis cenderung memahami teks secara rasional dan kontekstual terhadap konsep dan maksud nash tersebut. Sementara pemikiran tradisional cenderung memahami teks hukum secara literal, harfiah, dan terikat pada mazhab serta berpegang pada dhahir nash. Oleh karena itu perbedaan pendapat di kalangan umat Islam sampai kapanpun dan dimanapun akan terus berlangsung karena pola fikir manusia terus berubah dan berkembang.

Polarisasi pemikiran ulama dalam memahami suatu nash hukum seperti yang disebutkan di atas, bukan saja karena adanya dalil-dalil nash yang bersifat spekulatif dan persoalan-persoalan hukum yang tidak ada nashnya, tetapi juga karena faktor agama, bahasa, dan tabiat manusia, ${ }^{8}$ ikut memberi andil yang cukup efektif terjadinya konflik pemahaman. Sehingga dampak yang sering dialami oleh kebanyakan orang awam dalam menghadapi perbedaan pendapat tersebut adalah timbulnya kekisruan dan keributan bahkan saling mengejek serta tidak jarang mendatangkan kebencian, bahkan kematian sekalipun demi mempertahankan dan membela secara fanatik pendapat yang diyakini kebenarannya.

Agama yang disebut sebagai salah satu faktor pendukung terjadinya konflik, dapat dipahami karena agama membawa perintah dan larangan. Perintah dan larangan itu, terkadang menggunakan nash-nash secara eksplisit (mansukh 'alaih) dan juga terkadang menggunakan nash secara implisit (mansukh 'anhu).

Penggunaan nash mansukh sebagaimana yang disebutkan terkahir, memahaminya memerlukan proses ijtihad yang sungguh-sungguh dalam mengistimbathkan hukum, karena kandungan nash-nash dimaksud dalalahnya (petunjuknya) kurang begitu jelas maksud dan tujuan yang dikehendakinya. Berbeda dengan nash-nash yang bersifat muhkamat, dimana dalalah nash itu jelas, sehingga tertutup kemungkinan adanya perbedaan pemahaman dan interpretasi ulama dalam memahaminya. Adanya nash-nash Al-Qur'an yang mutasyabihat, menunjukkan bahwa teks-teks keagamaan yang berasal dari wahyu, yakni AlQur'an dipahaminya secara beragam sehingga memiliki potensi untuk saling bebeda dan silang pendapat di antara para ulama.

\footnotetext{
${ }^{7}$ M. Ali Hasan, Perbandingan Mazhab, (Jakarta: PT. Raja Grafindo Persada, 1996), h. 118

${ }^{8}$ Huzaemah Tahido Yanggo, op., cit., h. 65 - 66. Bandingkan dengan Yusuf Al-Qardhawi, Ijtihad alMu'ashir bayn al-Indhibath wa 'i-infirath, (Kairo: Dar al-Tawzi’wa an-Nasr al-Islamy, 1994), h. 23
} 
Hal yang sama, juga terjadi karena faktor bahasa. Al-Qur'an sebagai sumber utama ajaran Islam menggunakan lafadz dan bahasa Arab. Kebahasa araban AlQur'an, justru melahirkan perbedaan dan pemahaman, karena bahasa Al-Qur'an menggunakan lafadz multi makna, seperti lafadz musytarak, lafadz majaz (kiasan), am (umum), khas (tertentu), mutlaq, dan mugayad, dan lain sebagainya. ${ }^{9}$ Bentuk-bentuk pengungkapan bahasa Al-Qur'an inilah yang memberi peluang terjadinya interpretasi yang beragam dengan konsekwensi-konsekwensi yang beragam pula. Lafadz-lafadz tersebut untuk menyebutnya sebagai bentuk-bentuk spekulatif. Terlepas dari unsur-unsur penyebab terjadinya lafadz-lafadz spekulatif tersebut, yang jelas adanya pluralitas makna yang dikandung dalam satu lafadz nash atau kata telah membawa para mujtahid terlibat ke dalam konflik pemahaman dan pendapat sepanjang sejarah perjalanan hukum Islam.

Apa yang disebut dengan lafadz-lafazd yang bersifat spekulatif itu diakui oleh para ulama termasuk Imam Syafi'i sebagaimana yang dikutif Huzaemah, sebagai salah satu penyebab konflik pemahaman terhadap nash-nash hukum. ${ }^{10}$ Format dalil yang spekulatif atau dalam bahasa ushul fiqhi disebut kalimat musytarak, dapat diilustrasikan melalui makna dan kata " $y a^{\prime} f u$ " dalam surat Al-Baqarah ayat 237 yang menyatakan:

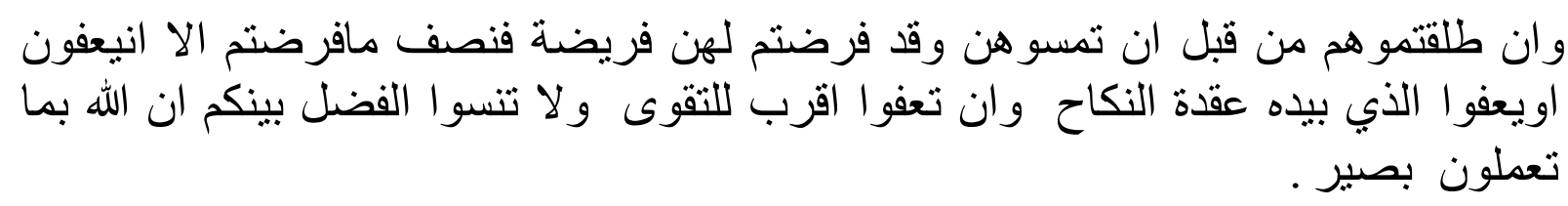

"jika kamu menceraikan istri-istrimu sebelum kamu bercampur dengan mereka, pada hal kamu telah menentukan maharnya, maka bayarlah seperdua dari mahar yang telah kamu tentukan itu, kecuali jika istri-istrimu itu memaafkan atau dimaafkan oleh orang-orang yang mempunyai ikatan nikah, dan pemaafan kamu itu lebih dekat kepada taqwa. Dan janganlah kamu melupakan keutamaan di antara kamu. Sesungguhnya Allah Maha Melihat segala apa yang kamu kerjakan." (Q.S, A-Baqara:237).11

Kata " $y a^{\prime} f u$ " dalam ayat tersebut adalah musytarak yang berarti menggugurkan (yasquthu) sekaligus berarti menghibahkan (yahaba). Sebagai konsekwensinya, Ibrahim, Al-Qamah, Hasan Malik dan Imam Safi'i dalam Qaul Qadimnya yang cenderung mengartikan kata "Alladzi biyadihi uqdatun al-nikah" dengan wali (sebagai orang yang membebaskan keharusan untuk membayar mahar yang separuhnya lagi merupakan hak anaknya), maka mereka lebih memilih makna "menggugurkan". ${ }^{12}$

Sebaliknya sejumlah ulama yang dipelopori oleh Ali bin Abi Thalib, Syuraih Sa'id bin Al-Musayyab, Abu Hanifah dan Imam Syafi'i dalam Qaul Jadidnya lebih memihak kepada makna yang kedua, yahaba sehingga sesuailah kalau yang

\footnotetext{
${ }^{9}$ Huzaemah Tahido Yanggo, op., cit., h. 65

${ }^{10}$ Ibid.,

11_QS., Al-Baqara (2): 237

${ }^{12}$ Huzaemah Tahido Yanggo, op., cit., h. 53
} 
dimaksud dengan "Alladzi biyadihi uqdatun al-nikah" adalah suami, analoginya karena suami dalam kasus perceraian dalam konteks ini hanyalah diwajibkan sebatas membayar mahar separuh dari mahar yang telah ditentukan sebelumnya, sedang ia sendiri membayar mahar penuh pada sang istri. ${ }^{13}$

Untuk menentukan yang mana di antara makna musytarak harus diikuti secara cermat dan tuntas. Tampaknya hal ini tidak sedikit orang berpaling pada kelihaian seorang mujtahid dalam melihat konteks dan situasi dimana kata-kata itu terdapat. Dalam konteks musytarak dengan muatan-muatan syari'ah, tentu prinsip-prinsip umum sekaligus tujuan-tujuan syari'ahlah sebagai ujung tombak dari konsiderannya.

Sebab lain dari adanya konflik pemahaman dan pendapat para ulama adalah yang juga berkenaan dengan Sunnah Rasul. Dari sisi sampai tidaknya hadis tersebut pada shahabat. Penilaiannya pada periwayatan serta posisi "syakhsyiyyah" dari Nabi itu sendiri. Para ulama sepakat bahwa sunnah merupakan sumber syari'ah kedua yang berdiri sejajar dengan Al-Qur'an. Pada sisi ini kesaksian Al-Qur'an berikut konsensus shahabat serta tingkat antusias dalam mentaati perintah-perintahnya dirasa cukup untuk menjustifikasi nilai autentisitasnya. Hanya ketika berhadapan dengan perbendaharaan sunnah yang diperoleh, tentu ada perbedaan di antara shahabat. Dalam hal ini tampaknya faktor kesempatan dan daya ingat mempunyai daya pesan yang cukup berarti. Shahabat yang aktif menghadiri majlis Rasul sudah dipastikan penerimaan berikut periwayatannya akan jauh melampaui yang sebaliknya.

Pada posisi yang disebutkan terakhir inilah konflik pemahaman dalam konteks Sunnah punya peluang untuk terjadi. Kasus yang paling banyak dirujuk di kalangan ushuliyyun dalam konteks ini adalah fatwa Ibnu Umar yang diriwayatkan oleh Imam Muslim bahwa "apabila seorang wanita mendi junub hendaknya membuka sanggulnya". Fatwa tersebut ternyata tidak hanya menjadikan Siti Aisyah terperanjat bahkan tidak cukup membuatnya penuh keheranan seraya berkata "Sungguh aneh Ibnu Umar ini memerintahkan kaum wanita apabila mereka mandi janabah untuk mengudar sanggul, jika demikian halnya apakah tidak lebih baik menyeruh mereka untuk mencukur rambutnya saja ?". Selanjutnya Aisyah meriwayatkan hadis mengenai soal ini yang mengatakan "sesungguhnya aku pernah mandi bersama Rasulullah saw., dari satu bejana dan aku menyiram rambut kepalaku tidak kebih dari tiga siraman". ${ }^{14}$

Kemudian penilaian seorang mujtahid terhadap hadis, baik dari sisi matan atau sanadnya maupun pada sisi yang lain, juga memberikan porsi terjadinya konflik pendapat tersebut. Kalaupun standar jarah watta'dil telah diformulasikan, bukan berarti seorang yang dianggap adil oleh seorang ulama, akan dianggap adil pula oleh ulama yang lain, justru tidak menutup kemungkinan jatuh pada kategori dhaif

\footnotetext{
${ }^{13}$ Ibid.,

${ }^{14}$ Ibid., h. 55
} 
bahkan bisa ditolak sama sekali (seperti yang terjadi bagi kalangan ulama syi'ah yang menerima hanya riwayat kalangan Ahlu-bait).

Contoh penilaian hadis dalam segi sanad adalah hadis tentang wajibnya membaca al-Fatihah bagi seorang makmun dalam shalat yang diriwayatkan oleh Ubadah yang mengatakan "Dari Ubadah bin Shamit, ia berkata bahwa Rasulullah telah shalat subuh agak panjang bacaannya, maka setelah selesai shalat, Rasulullah berkata, "Aku memperhatikan kalian membaca di belakang imam" , kami menjawab, "Ya Rasul, Demi Allah memang kami membaca", Rasulullah berkata, "janganlah kalian membaca, kecuali ummul qur'an (al-fatihah) karena sesungguhnya tidak sah shalat seseorang yang tidak membacanya". (HR. Abu Daud). ${ }^{15}$

Imam Syafi'i adalah salah seorang yang mendukung wajibnya membaca alfatihah bagi makmun dalam shalat dengan merujuk pada hadis di atas, sementara Ibnu Qatadah dalam kitabnya Al-mughni tidak ada yang meriwayatkan kecuali Ibnu Ishaq dan Nafi bin Mahmud, sedangkan Ibnu Ishaq masuk kategori mudallis, sementara Nafi' sendiri jauh lebih rendah lagi. Dari inilah muncul dua pendapat yang mendukung wajib dan tidaknya membaca al-fatihah. ${ }^{16}$

Pada sisi yang lain, penilaian pada posisi Nabi walaupun skalanya relatif sedikit, juga merupakan faktor dari munculnya perbedaan pendapat. Nabi di samping kapasitasnya sebagai Rasul, beliau juga sebagai seorang Imam (kepala negara) sekaligus sebagai seorang hakim, untuk itu tindakan dan ucapan Rasul tidaklah sama kedudukannya. Tentu kalau kapasitasnya sebagai Rasul, Nabi meletakkan ketentuan-ketentuan yang tidak dicetuskan oleh Al-Qur'an. Oleh karena itu, dalam kapasitas ini sunnah bisa berupa klasifikasi bagian Al-Qur'an yang bersifat ambiguitas (mujmal) atau spesifikasi serta kwalifikasi kandungan Al-Qur'an yang umum.

Apapun yang disahkan oleh Nabi mengenai prinsip-prinsip agama, khususunya dalam soal-soal fakultatif (ibadah), ketentuan yang menjelaskan halalharam adalah legalisasi umum (tasyrik am) yang validitasnya tidak terbatas dalam lingkungan waktu, dan keadaan serta mengikat setiap ummat Islam tanpa harus melihat keadaan individual, status sosial atau pun jabatan politis, maka bertindak atas jalan inilah yang tidak memerlukan pengesahan dari pimpinan agama atau pun pemerintah. ${ }^{17}$

Berbeda dengan ketentuan sunnah yang berasal dari Nabi dalam kapasitasnya sebagai kepala negara atau Imam, seperti dengan pendistribusian harta rampasan perang, alokasi dan pembelanjaan dana publik serta corak ketentuan kenegaraan lainnya, kalaupun hal ini termasuk dalam kategori Sunnah legal, tetapi ketentuanketentuan tersebut tidak termasuk pada bagian legislasi umum (tasyrik am). Sunnah jenis inilah yang tidak bisa dipraktekkan oleh individu-individu dengan inisiatif

\footnotetext{
${ }^{15}$ Ibid., h. 57

${ }^{16}$ Ibid., h. 56

${ }^{17}$ Muhammad Fathi, Buhutsu Nuqaranati fi al-Fiqhi wa Ushulihi, (Bairut: 1994), h. 513
} 
dirinya sendiri tanpa memperoleh lecensi lebih awal dari otoritas pemerintah yang berwewenang, kecuali bila ada indikasi yang menunjukkan sebaliknya. Tanpaknya untuk ketentuan Sunnah yang terakhir inilah yang relatif memberikan ruang gerak munculnya perbedaan ulama. ${ }^{18}$

Pada sisi lain, konflik juga dapat terjadi karena faktor tabiat manusia. Hal ini dapat dipahami, karena manusia sebagai mahluk ciptaan Tuhan, secara fitriah memiliki sifat dasar yang berbeda-beda, dan ini merupakan sunnahtullah. Al-Qur'an mengimformasikan sifat dasar manusia itu, untuk selalu berbeda, karena itulah Allah kemudian mengutus seorang rasul untuk menengahi dan membimbing manusia ke jalan yang lurus (QS, 2: 213). Jika suatu saat, manusia berselisih pendapat terhadap permasalahan yang mereka hadapi, selayaknya mereka mengembalikan masalah tersebut kepada Allah dan Rasulnya (QS,4:59).

Kembali kepada Allah dan Rasulnya sebagaimana yang disbutkan terakhir, dimaksudkan, yakni kembali kepada Al-Qur'an dan Hadis Nabi saw, melalui ijtihad. Dalam proses ijtihad sebagai bentuk kembali kepada Allah dan Rasul inilah potensi konflik pemahaman dalam memahami nash terjadi, dan mewarnai perjalanan sejarah manusia hingga detik ini.

Munculnya madzhab fiqh sekitar abad ke- $3 \mathrm{H}$ seperti empat madzhab besar fiqh ahl-as-Sunnah, -- Abu Hanifah Malik, Syafii, dan Ahmad ibn Hambal, -semakin mengkristal dan menjadi suatu kemestian (determine) yang tidak bisa dihindari. Para ulama pun tidak sedikit terjerat kepada kaedah-kaedah salah satu dari empat madzhab fiqhi dan hal itu tidak jarang membuat umatnya fanatik terhadap imam-imam madzhab mereka. Implikasi munculnya madzhab terhadap masyarakat Islam yang masih awan, relatif kurang menguntungkan, sebab perbedaan yang terjadi walau amat kecil, tetapi dapat menimbulkan kekisruan bahkan clash fisik. ${ }^{19}$

Kekisruan yang terjadi sebagai akibat perbedaan pendapat itu, bagi kalangan intelektual, justru memberikan kontribusi yang sangat positif bagi pemikiran hukum Islam, membuat integritas umat, dan orang menjadi dewasa. Atas dasar itu, maka sikap yang perlu ditumbuhkembangkan dalam konteks ini adalah sikap saling menghargai dan menghormati, hal ini disebut sebagai sikap inklusif dalam beragama. Dan ini sangat ditekankan oleh para pembaharu seperti Muhammad Rasyid Ridha, yang menganjurkaan agar orang tidak perlu terlalu fanatik dalam bermadzhab, karena sikap fanatik membuat orang eksklusif, merasa benar sendiri dan yang lain salah. Sikap ini masih kental dimasyarakat Indonesia, seperti munculnya konflik berkepanjangan antara Muhammadiyah dan Nahdhatul Ulama (NU) hanya karena qunut dan tidak qunut, jumlah rakaat dalam sholat Tarawih,

${ }^{18}$ Sulaiman, “Af 'alirrasul wa Dilalatuha ala al-Ahkami al-Syari'ah”, Arrisalah, (tt,. Tp., t.t. ), h. 25

19 Muhammad Mustafa Asy-Syak'ah, Islam Tidak Bermadzhab. Terjemahan Oleh: A.M. Basalaah dari Islam Bila Madzhab. (Jakarta: Gema Insani press, 1995), h. 5 
sebelas atau dua puluh tiga. Meskipun hal itu termasuk dalam persoalan furu'iyah, namun memicu komflik di masyarakat.

Oleh karena itu sebagian kalangan yang dianggap 'terpelajar' perlu adanya sikap toleran dan ukhuwa serta "tidak memihak" terhadap mana yang paling 'mutlak benar' karena tidak ada yang 'paling mutlak' salah.

\section{SOLUSI KONFLIK HUKUM ISLAM HASIL IJTIHAD}

Dalam menyikapi konflik hasil ijtihad para ulama sebagaimana dikemukakan di atas, terdapat pendekatan dalam pemikiran yang dapat digunakan dalam memberikan tanggapan terhadap berbagai konflik hukum Islam. Tanggapan itu dapat dilihat melalui pendekatan reformatif. Pendekatan ini mengacu pada realitas hukum Islam hasil ijtihad para ulama sebagai kearngka awal dalam menyelesaikan konflik hukum yang terjadi, selain itu dapat juga menggunakan pendekatan ukhuwa dan toleransi terhadap pluralitas hukum Islam. Pendekatan yang disebutkan terakhir, merupakan variabel pendukung terhadap pendekatan pertama di atas.

Pendekatan reformatif memandang bahwa hukum Islam harus tetap berjalan seperti pada masa awal Islam hingga saat ini dan seterusnya. Perbedaan pendapat di kalangan ulama mengenai suatu persoalan hukum membutuhkan dukungan cara berpikir rasional, ilmiah dan berpikir kritis terhadap berbagai persoalan hukum Islam haril ijtihad tersebut, dengan memisahkan secara tegas antara dalil-dalil nash yang sifatnya defintif (qath'i) dengan dalil-dalil nash yang spekulatif (dhanny), atau yang bersifat substansi dengan yang bersifat furu'iyyah. Oleh karena itu pemikiran hukum Islam menggariskan pendekatan reformatif atau pendekatan yang lebih menagkap ide moral Islam dari pada aspek legal-formalnya. Hukum Islam dipahami secara kontekstual substantif dan apresiatif terhadap perkembangan dan perubahan sosial masyarakat sehingga hukum-hukum yang lahir itu menjadi solusi terhadap probem yang dihadapi manusia.

Dengan pemikiran substantif dimaksudkan sebagai aksentuasi, bahwa penyelesaikan problem umat jauh lebih penting dari sekedar memahami teks-teks wahyu yang sifatnya terstual tanpa upaya berijtihad untuk menemukan hukum yang benar dan mendatangkan mashlahah bagi umat.

Selain pendekatan yang dikemukakan di atas, juga pendekatan ukhuwa dan toleransi. Toleransi diperlukan karena memang ada perbedaan, dan perbedaan itu harus dihormati. Sikap saling menghargai dan memberi penghormatan terhadap perbedaan itu sangat penting. Sikap yang disebutkan ini, bisa terwujud secara efektif apabila perbedaan itu dikelola dengan baik, dengan didasarkan kepada niat yang jujur dan menyadari akan tanggung jawab bersama, serta dipergunakan sebagai ajan mengasah otak untuk memperluas cakrawala pandang serta memberikan ruang dioalog yang efektif kepada pihak lain yang berbeda pendapat. Hal ini, tentu akan sangat bermanfaat dan memberikan solusi bagi umat dan sekaligus mendinamisasikan hukum Islam itu sendiri. 
Berbeda pendapat adalah sesuatu yang penting dan diperlukan dalam berijitihad, asalkan dikelolah dengan baik dan benar. Dalam konteks ini, Yusuf AlQardhawi merumuskan aturan main berbeda pendapat agar hasilnya dapat menjadi solusi dan bermanfaat, bagi umat, yaitu:

1. Berijitihad harus secara sungguh-sunggu, sebab tanpa usaha yang sungguhsunggu dan serius dalam istimbat hukum, maka tidak dinamakan berijitihad,

2. Ijtihad tidak boleh dalam masalah-masalah yang baku (qath'iyyah);

3. Tidak boleh berijitihad untuk menjadikan hukum yang bermuatan hukum zhanniy lalu diubah menjadi qath'i,

4. Dalam berijtihad, fiqh dan hadis tidak boleh dipisahkan,

5. Berijtihad berarti menerima segala yang baru dan bermanfaat serta memelihara yang lama yang masih bermanfaat,

6. Tidak terikat kepada empat mazhab saja seiring dengan berubahnya zaman, dan

7. Berijtihad jama'i akan lebih dekat kepada kebenaran dari pada ijtihad yang fardhiy. ${ }^{20}$

Apa yang dirumuskan Yusuf Qardhawi di atas, merupakan sebuah ikhtiar dan upaya mengkanalisasi setiap perbedaan pendapat agar tidak keluar dari konteks ijtihad yang sesungguhnya. Meskipun hukum-hukum hasil ijtihad tersebut diperselisihkan, namun tetap dihargai dan diterima dengan sikap tolerans di antara mereka yang perbeda pendapat, karena adanya kesungguhan dan makasimal dalam berijtihad, sehingga hukum-hukum Islam hasil ijtihad tersebut terasa bermanfaat dan menjadi solusi terhadap persoalan umat.

Fikih sebagai hasil ijtihad ulama dari sumbernya yang utama, Al-Qur'an dan As-Sunnah, demikian beragam karena berasal dari latar belakang pemikiran dan pendapat yang berda beda dalam melihat suatu peristiwa hukum atau kejadian hukum. Namun keragaman hukum hasil ijtihad akan mendatangkan manfaat dan menjadi solusi jika perbedaan tersebut berpijak pada aturan main yang disebutkan di atas.

Konflik dan ijtihad yang telah dimulai pada masa shahabat menjadi inspirasi bagi generasi sesudahnya, karena para shahabat telah memberikan contoh yang baik kepada umat mengenai cara-cara berijtihad yang benar. Selama pencaharian hukum lewat ijtihad itu disertai dengan keikhlasan dan shering ilmu, hal itu tidak akan mempengaruhi persatuan dan kesatuan umat, tetapi justru akan melahirkan umat yang cerdas, memiliki integritas yang tinggi, dan mandiri.

Kekayaan dan tradisi berijtihad yang menjadi supermasi mencaharian hukum-hukum Islam pada masa awal Islam, ${ }^{21}$ benar-benar mendinamisasikan hukum Islam dan dapat menghentikan kejumudan serta membuka pintu kemudahan. Dalam hubungan ini, Ali Hasan dengan bahasa yang lebih mudah

${ }^{20}$ Yusuf Al-Qardhawi, op., cit., h. 7

21 Muhammad Abu Zahrah, Tarikh al-Madzahib al-Fiqhiyah, (Kairo: Mathba' al-Madaniy, tt., ), h. 28 
dipahami mengatakan, bahwa perbedaan pendapat dalam memahami hukumhukum Islam hasil ijtihad dapat membawa manfaat, karena antara lain:

1. Dapat menghidupkan fikiran manusia melalui ijtihad sebab dalam berijtihad akan terjadi shering pikiran dan aduh argumentasi dengan seksama dalam majlis ilmu (ijtihad), tanpa ijtihad, akan lemahlah kemampuan berfikir manusia. Hal ini bertentangan dengan ajaran Islam;

2. Mengatasi dan memecahkan kesulitan-kesulitan yang ditemui dalam masyarakat atau kehidupan manusia, karena berdasarkan kenyataan pada saat ini semakin banyak persoalan yang timbul;

3. Memelihara kepentingan esensial dalam kehidupan manusia, seperti memelihara keselamatan agama, jiwa, akal, keturunan, dan harta benda dan lain-lain;

4. Sebagai alat pencari kebenaran terhadap penyelesaian perkara yang timbul, baik berdasarkan dalil yang ada nashnya maupun yang tidak ada nashnya;

5. Sebagai salah satu metode atau jalan terbaik dalam mempertimbangkan ayat AlQur'an yang dapat diterapkan dalam suatu situasi tertentu dan yang tidak dapat diterapkan;

6. Jika ijtihad hidup dan berkembang, maka hukum Islam berkembang pula secara dinamis;

7. Melalui ijtihad dibuktikan bahwa ajaran Islam itu tetap relevan di setiap tempat dan waktu. (Al-Islam Sholihun li kulli zaman wa makan). ${ }^{22}$

Kutipan di atas, merupakan sebuah tindakan solutif atas adanya konflik hukum Islam hasil ijtihad ulama, karena perbedaan pendapat itu dapat mendorong perkembangan dan lahirnya hukum-hukum baru guna memecahkan persoalanpersoalan umat, termasuk masalah-masalah yang ditimbulkan oleh perkembangan ilmu pengetahuan dan teknologi.

Upaya bagi penyelesaian terhadap pengaruh perkembangan ilmu pengetahuan dan teknologi, dipandang kurang cukup hanya dengan menggunakan ijtihad individual (fardi) saja, karena umat Islam diperhadapkan oleh berbagai persoalan baru dan kompleks, dari sinilah kemudian diperlukan penalaran yang lebih cerdas lagi dalam menopang kehidupan dan perkembangan hukum Islam. Prinsip yang dipakai dalam soal ini adalah beralih dari ijtihad individual ke ijtihad kollektif (jama'i). Pengalaman masa lalu menjadi pelajaran, ketika ijtihad tersebut selama bertahun-tahun telah ditinggalkan oleh umat Islam, membawa dampak negatif terhadap hukum Islam, menjadi kaku dan statis. Hal ini didukung pula dengan munculnya kaum konservatisme dalam Islam yang berpandangan bahwa rasionalisme yang ditimbulkan mu'tazila akan membawa kepada disintegrasi yang mebahayakan kesatuan politik Islam. ${ }^{23}$

${ }^{22}$ M. Ali Hasan, op. cit., h. 93

${ }^{23}$ Harun Nasution, Pemharuan Dalam Islam, Sejarah Pemikiran dan Gerakan, (Jakarta: Bulan Bintang, 1975), 191 
Dengan tidak berkembangnya ijtihad, terutama ijtihad kolektif merupakan hal utama yang membawa kemunduran umat Islam, puncaknya berawal dari kehancuran Baghdad sebagai pusat kemajuan pemikiran dan peradaban umat Islam di pertengahan abad ke-13 $\mathrm{H}$.

Penginterpretasin atau peralihan ijtihad sebgaimana disebutkan di atas, adalah beralih dari ijtihad individual ke ijtihad kollektif (jama'i). Ijtihad kolektif tersebut dilakukan dalam satu lembaga legislatif Islam. Lembaga ini tidak hanya didukuki oleh ulama yang mempunyai otoritas untuk menafsirkan Islam, tetapi juga oleh para ahli dari berbagai disiplin ilmu. Mereka disebut sebagai orang awam tentang hukum Islam, tetapi memiliki pandangan yang tajam tentang masalah-masalah kemasyarakatan. Oleh sebab itu tidak lagi memberikan persyaratan ulama saja pada orang yang duduk di lembaga ijtihad tersebut, tetapi didasarkan pada kebutuhan dan kepentingan terhadap masalah dan peristiwa yang akan ditetapkan hukumnya. ${ }^{24}$

Hkum-hukum hasil ijtihad yang dilakukan secara kollektif semacam itu, hasilnya dapat menjadi solusi bagi penyelesaian berbagai persoalan yang dihadapi umat terutama pada abad modern seperti sekarang ini yang semakin kompleks.

\section{KESIMPULAN}

Dari beberapa penjelasan yang dikemukakan di atas, dapat ditarik kesimpulan bahwa konflik sebagai hasil ijtihad merupakan sebuah keharusan yang tidak bisa dihindari. Oleh karena itu sikap yang harus diambil adalah bersikap terbuka (inklusif) dalam menyikapi setiap persoalan dan perbedaan pendapat di kalangan umat Islam bukan sebaliknya, bersikap fanatik. Dan bagi seorang muslim yang terpelajar sikap yang perlu dibangun dan ditumbuhkan adalah tetap melakukan pengkajian Islam dan mengetahui dengan pasti asal-muasal dan akar persoalan yang diperdebatkan untuk kemudian mengambil yang dianggapnya lebih benar tetapi tidak menafikan adanya kemungkinan yang lain lebih benar. Dengan cara seperti ini, kita termasuk ikut mrmbantu mengatasi persoalan umat dengan cara-cara yang bijak dan toleran.

Bahwa konflik merupakan perbedaan pendapat di antara ahli hukum Islam yang bersifat furu'iyah (cabang), bukan pada hukum Islam yang bersifat ushuliyah (pokok). Perbedaan pemahaman dalam menetapkan satu masalah atau kejadian, karena disamping adanya unsur-unsur spekulatif, baik external maupun internal pada dalil-dali syara', baik yang disepakati maupun yang tidak, serta perbedaan metodologi yang digunakan, hal ini menjadi sebab adanya perbedaan tersebut, dan perbedaan pendapat itu merupakan sebuah keniscayaan dan sekaligus sebagai khazanah hukum Islam itu sendiri.

Bahwa pendekatan yang digunakan dalam menyelsaikan setiap konflik hukum Islam hasil ijtihad adalah pendekatan reformatif dan toleran terhadap setiap

${ }^{24}$ Muhammad Iqbal, Rahasia-rahasia Pribadi. Terjemahan Oleh Bahrun Rangkuti dari Asrar-i-Khudi, (Jakarta: Bulan Bintang, 1976), h. 174 
perbedaan. Pendekatan reformatif dan toleran memerlukan dukungan cara berpikir yang rasional, kritis, dan bersungguh-sungguh melakukan penggalian hukum Islam dalam rangka menjawab setiap persoalan umat, meskipun hasilnya berbeda-beda dan diperselisihkan, namun tetap dihargai karena didasarkan pada sikap kebersamaan mencari kebenaran sebagai upaya mewujudkan maqashid syar'iyyah demi kemaslahatan umat.

\section{Daftar Pustaka}

Abu Zahrah, Muhammad, Tarikh al-Madzahib al-Fiqhiyah, Kairo: Mathba' al-Madaniy, tt.

Dewan Redaksi, Ensiklopedi Islam, Jakarta: PT. Ichtiar Baru Van Hoeve, 1993.

Fathi, Muhammad, Buhutsu Nuqaranati fi al-Fiqhi wa Ushulihi, Bairut: 1994.

Hasan, M. Ali, Perbandingan Mazhab, Jakarta: PT. Raja Grafindo Persada, 1996.

Iqbal, Muhammad, Rahasia-rahasia Pribadi. Terjemahan Oleh Bahrun Rangkuti dari Asrar-i-Khudi, Jakarta: Bulan Bintang, 1997.

Yanggo, Huzaemah Tahido, Pengantar Perbandingan Mazhab, Jakarta: Logo Wacana Ilmu, 1997.

Mustafa Asy-Syak'ah, Muhammad, Islam Tidak Bermadzhab. Terjemahan Oleh: A.M. Basalaah dari Islam Bila Madzhab. Jakarta: Gema Insani press, 1995.

Nasution, Harun, Pemharuan Dalam Islam, Sejarah Pemikiran dan Gerakan, Jakarta: Bulan Bintang, 1975.

Al-Qardhawi, Yusuf, Ijtihad al-Mu'ashir bayn al-Indhibath wa 'i-infirath, Kairo: Dar alTawzi'wa an-Nasr al-Islamy, 1994.

Sulaiman, "Af 'alirrasul wa Dilalatuha ala al-Ahkami al-Syari'ah", Arrisalah, tt,. Tp., t.t. 1975. 